\title{
The energy requirement for maintenance and production of laying hens
}

\author{
A. H. M. Grimbergen \\ Schothorst Institute for Modern Livestock Nutrition, Hoogland (Amersfoort), \\ the Netherlands
}

Received : 21 May 1970

\section{Summary}

Respiration experiments were applied to fasting laying hens in an attempt to estimate the 'heat expenditure for synthesis' of eggs from body reserves. The equation $\mathrm{H}=$ $85.2 \times \mathrm{W}^{0.75}+16.6$ was found for the regression from heat production $(\mathrm{H})$ to metabolic weight $\left(\mathrm{W}^{0.75}\right)$. It was concluded from this regression equation that about $20 \mathrm{kcal}$ of heat are evolved in the production of every $100 \mathrm{kcal}$ of egg substance from body substance.

Energy balance experiments were then conducted on a total of 37 laying hens fed ad libitum in batteries. From these experiments a calculation was made of the regression from the energy balance (Y) to the intake of metabolizable energy (X), both calculated per unit of metabolic weight (W0.75). In the case of a negative total balance (B), a correction of $0.2 \mathrm{~B}$ was applied to the amount of heat evolved. The regression equation found was $\mathrm{Y}=0.642 \mathrm{X}-65.7$.

It was concluded from this regression equation that under the experimental conditions the efficiency of utilization of the metabolizable energy for production was $64.2 \%$ $( \pm 5.5 \%$ ) and the maintenance requirement $102 \pm 7.6 \mathrm{kcal} \mathrm{kg-0.75}$.

The results of the experiment were compared with entirely parallel experiments under practical conditions (birds kept in batteries and on litter). Considerable discrepancies were found between the results of the two experiments. It was assumed that the most likely cause of these discrepancies was a difference in environmental conditions as a result of which the birds' maintenance requirement during the practical experiments may have been higher.

\section{Introduction}

It has become increasingly customary of late to express the energy value of poultry food in calories of metabolizable energy. This is a very good practical yardstick for the formulation of diets but there is very little reliable published evidence as to which part of the metabolizable energy is used by laying hens for maintenance and which part for production. True an attempt has been made on the basis of a very large number of practical-scale dietary experiments to draw up a regression equation by means of which the feed consumption of laying hens can be calculated as a function of the body weight, egg production and possible growth. One of the best known formules is that of Byerly which was converted by Combs to energy requirements (Combs, 1962). 
In theory the problem can be solved by carrying out energy balance experiments, as was done for example by Waring and Brown $(1965,1967)$. In these experiments they made use of closed circuit respiration chambers in which the energy metabolism of a single laying hen was measured for a 24-hour period. Measurements were only taken of a few birds. Both starved fowls were measured and fowls kept at different planes of nutrition. These experiments ignored the fact that some birds were producing eggs despite being in a state of negative energy balance, and that this egg production at the expense of the bird's own body reserves is accompanied by low heat production. According to Waring and Brown, the efficiency of utilization of the metabolizable energy for both maintenance and production is about $85 \%$. As regards egg production this figure is very high. Far lower utilization percentages for protein and fat production have been found in other kinds of animals, viz 62-77\% in pigs by Jenkinson (1967), $66 \%$ in fattening calves (van Es et al., 1966), and 70.6\% in rats (Vermorel, 1967); for pigs and rats the highest utilization percentages given by Nehring et al. (1961) for the formation of body fat from groundnut oil were 85.9 and 83.1, respectively.

The utilization percentage obviously depends on the composition of the diet (fat, protein and carbohydrate content) and the fat/protein ratio of energy retention (Blaxter, 1962).

In our laying hen trials we started from rations normally used in practice. The animals used for the energy balance experiments were taken from other dietary and housing experiments carried out at our Institute in order to make possible a comparison with practical conditions (Stappers, 1969). Practical conditions were also deliberately simulated by carrying out most measurements on more than one animal in each respiration chamber. The feeding levels were not artificially restricted as in Waring and Brown's experiments $(1965,1967)$, although in some cases the heat production of fasting animals was measured.

\section{Materials and methods}

\section{Calculations, definitions and nomenclature}

The mensurable values in energy balance experiments on laying hens are the metabolizable energy (M.E.), heat production (H), and calorific value of the eggs produced (E.E.). When M.E. = H + E.E. the animal is in a state of energy balance. But it is also possible for the animal to produce body fat or protein in addition to eggs, or for a part of the energy utilization for egg production to be of endogenous origin rather than from the M.E. This amount of energy cannot be directly determined but may be calculated from B $=$ M.E. $-\mathrm{H}-$ E.E. Hence $\mathrm{B}$ may be either positive or negative. The amount of heat produced may be split up into a part required for maintenance $(\mathrm{Hm})$ and a part consisting of the heat expenditure for synthesis (Hs) which is lost in the production of eggs or body substances from M.E.: $\mathrm{H}=\mathrm{H}_{\mathrm{m}}+\mathrm{H}_{\mathrm{s}}$.

Consequently $\mathrm{H}_{\mathrm{m}}$ is an operand, viz the amount of heat produced by a fowl maintained on a normal ration and producing $0 \%$ eggs, and in a state of energy balance.

From the theoretical viewpoint $\mathrm{H}_{\mathrm{s}}$ depends on the nature of the synthesized materials (fat, protein) and the basic materials from which they are synthesized, e.g. fat from carbohydrates, fat from fat supplied in the ration, egg fat from body fat, and so on. A great many different possibilities are conceivable:

$\mathrm{H}_{\mathrm{s}}=\mathrm{H}_{\mathrm{s}_{1}}+\mathrm{H}_{\mathrm{s}_{2}}+\mathrm{H}_{\mathrm{s}_{3}} \ldots \mathrm{H}_{\mathrm{s}_{\mathrm{n}}}$. 
Lastly, a few simplifications were introduced to enable some conclusions to be drawn from the fairly limited amount of experimental material, viz:

1 As regards heat expenditure for synthesis, no distinction was drawn between the synthesis of eggs and the synthesis of body material; since most of the growth of adult animals is in the form of fat and about $60 \%$ of the energy laid down in eggs consists of fat, it is clear that this simplification was not a source of any considerable error. It was also assumed that the heat expenditure for synthesis is directly proportionate to the calories produced, i.e. $\mathrm{H}_{\mathrm{s}}=\mathrm{q}(\mathrm{ME}-\mathrm{H})$.

2 It is assumed that 20 calories of heat expenditure for synthesis are released per 100 egg calories synthesized from the body reserves (viz an efficiency of about $83 \%$ ). We believe the present article affords some basis for the estimation of this value..

3 The maintenance requirement was assumed to be proportionate to the body weight of the experimental animals to the three-fourths power, i.e. $\mathrm{pW}^{\mathbf{0}} \mathbf{7 5}$. Thus when $\mathbf{B}=$ M.E. - H - E.E. $\geqslant 0$, M.E. = (M.E. - H) + pW0.75 $+q$ (M.E. - H), p and $q$ being constants. Alternatively, per unit of metabolic weight

$\frac{(\mathrm{M} . \mathrm{E} .-\mathrm{H})}{\mathrm{W}^{0.75}}=\mathrm{a} \frac{\mathrm{M} . \mathrm{E} .}{\mathrm{W}^{0.75}}-\mathrm{b}$

$\mathrm{a}$ and $\mathrm{b}$ being constants.

And when $\mathrm{B}=$ M.E. $-\mathrm{H}-$ E.E. $<0$, M.E. $=$ M.E. $-(\mathrm{H}-0.2 \mathrm{~B})+\mathrm{H}-0.2 \mathrm{~B}$, it being assumed that in this case, per 100 calories $\mathrm{B}, 20$ calories of heat are produced which are not derived from the absorbed, measured metabolizable energy.

Alternatively, M.E. $=$ M.E. $-(\mathrm{H}-0.2 \mathrm{~B})+\mathrm{pW} 0.75+\mathrm{q}\{$ M.E. $-(\mathrm{H}-0.2 \mathrm{~B})\}$, viz per unit of metabolic weight

$\frac{\text { M.E. }-\mathrm{H}+0.2 \mathrm{~B}}{\mathrm{~W}^{0.75}}=\mathrm{a} \frac{\text { M.E. }}{\mathrm{W}^{0.75}}-\mathrm{b}$

It follows from Eq. 1 and 2 that the efficiency of utilization of M.E. for production (factor a) and the maintenance requirement (b/a) can be estimated by calculating the regression from $\frac{M-H}{W^{0.75}}$ (or $\frac{M-H+0.2 B}{W^{0.75}}$ ) to $\frac{M . E .}{W^{0.75}}$.

The heat production was calculated from the respiratory exchange by means of Brouwer's (1964) formula. According to Romijn et al. (1969), correction for urine-nitrogen is so small as to be of no importance:

$\mathrm{H}=3.866\left(\right.$ litre $\left.\mathrm{O}_{2}\right)+1.200$ (litre $\left.\mathrm{CO}_{2}\right)$

One difficulty encountered in laying hens is that calcium carbonate is fixed in the egg shell, i.e. about $2 \mathrm{~g}$ of calcium per egg in the form of $\mathrm{CaCO}_{3}$, or $2.2 \mathrm{~g} \mathrm{CO}_{2}(1.12$ litre). This amount of $\mathrm{CO}_{2}$ has to be added to the $\mathrm{CO}_{2}$ exhaled via the lungs. But when animals are fed on a normal diet, the calcium requirement is largely taken up from the feed in the form of $\mathrm{CaCO}_{3}$. The diets employed by us contained about $5 \% \mathrm{CaCO}_{3}$. A daily intake of $100 \mathrm{~g}$ per animal will produce 1.12 litre $\mathrm{CO}_{2}$ provided all $\mathrm{CaCO}_{3}$ is dissolved in the gastrointestinal tract. Consequently there is little point in correcting the measured amount of exhaled $\mathrm{CO}_{2}$ of laying hens fed on a normal diet, since $\mathrm{CO}_{2}$ fixed in the egg shell is approximately equal to the $\mathrm{CO}_{2}$ produced in the gastrointestinal tract from $\mathrm{CaCO}_{3}$; hence in the case of fasting animals 1.12 litre $\mathrm{CO}_{2}$ per egg was in- 
variable added to the amount of $\mathrm{CO}_{2}$ measured. But no correction was made for animals maintained on a normal feeding régime, even when their production was very low. In such cases, therefore, the measured $\mathrm{CO}_{2}$ production may have been rather on the high side, although, as Eq. 3 shows, the amount of $\mathrm{CO}_{2}$ has far less effect on $\mathrm{H}$ than the $\mathrm{O}_{2}$ intake.

\section{Methods}

The respiratory exchange of the animals was measured in respiration chambers of transparent plastic material. The chambers consisted of a hood fitting into a rectangular trough filled with a layer of oil or water. The trough was hermetically mounted on a platform. All supply and discharge lines (air, water, electricity, cooling) were mounted in this platform, on which was also arranged an aluminium heat-exchanger which could be cooled with freon, thereby maintaining the relative humidity in the respiration cell at $65 \%-70 \%$. The battery cages which housed the experimental animals throughout the experiment could be placed on the platform, so that there were no difficulties of adaptation; the temperature in the chamber was kept constant at $20^{\circ} \mathrm{C}$.

Ventilation was provided by a diaphragm pump of which the supply voltage was stabilized so that fluctuations in the ventilation rate never exceeded $0.5 \%$. The outgoing air was continuously passed through a wet gas meter so as to provide a constant check on the ventilation rate. A humidifier was arranged in front of the gas meter in order to saturate the air with water vapour, thereby keeping the water level of the gas meter constant. The composition of the outgoing and incoming air was measured continuously with two gas analysers. For measuring the $\mathrm{CO}_{2}$ use was made of a Grubb-Parsson infrared apparatus and a Beckmann $\mathrm{O}_{2}$-analyser operating on the paramagnetic principle for measuring $\mathrm{O}_{2}$-concentration. A programme clock was used for passing fresh outside air through the instruments a few minutes hourly, and the sensitivity and zero point of the $\mathrm{CO}_{2}$ analyser were automatically controlled. Before and after each 24-hour measurement the instruments were calibrated with a known gas mixture. The accuracy of each instrument is about $0.005 \%$ absolute for a full scale deflection of $1 \% \mathrm{O}_{2}$ or $\mathrm{CO}_{2}$. To ensure proper functioning of the entire equipment it was found necessary to place them in a separate chamber with a constant temperature $\left( \pm 0.5^{\circ} \mathrm{C}\right)$. The supply voltage was also stabilized.

The entire equipment was calibrated by passing pure $\mathrm{CO}_{2}$ or $\mathrm{N}_{2}$ at a measured, constant speed into the chamber at a constant ventilation rate. When the $\mathrm{CO}_{2}$ or $\mathrm{O}_{2}$ concentration in the outgoing air had become constant for about 2 hours the $\mathrm{CO}_{2}$ or $\mathrm{N}_{2}$ supply was cut off, the measurements being continued for a further few hours. The volume of the chamber was calculated from the resultant purely logarithmic concentration-time curve (Struss, 1958). The weight of the animals multiplied by 1.3 was deducted from the volume determined in this way. The amount of $\mathrm{CO}_{2}$ or $\mathrm{N}_{2}$ supplied hourly was calculated from the horizontal part of the curve and compared with the amounts dosed. An average of $100.1 \%$ of the calculated value $(99.2 \%-100.6 \%)$ was found from 12 determinations with $\mathrm{N}_{2}$. The standard deviation of a single determination was $\pm 0.5 \%$; about the same results were obtained by calibration with $\mathrm{CO}_{2}$ gas. The entire equipment is shown diagrammatically in Fig. 1.

The oxygen consumption and $\mathrm{CO}_{2}$ production of the experimental animals were calculated from the resultant curves every 24 hours.

The metabolizable energy was determined with $\mathrm{Cr}_{2} \mathrm{O}_{3}$ as indicator and calculated by 


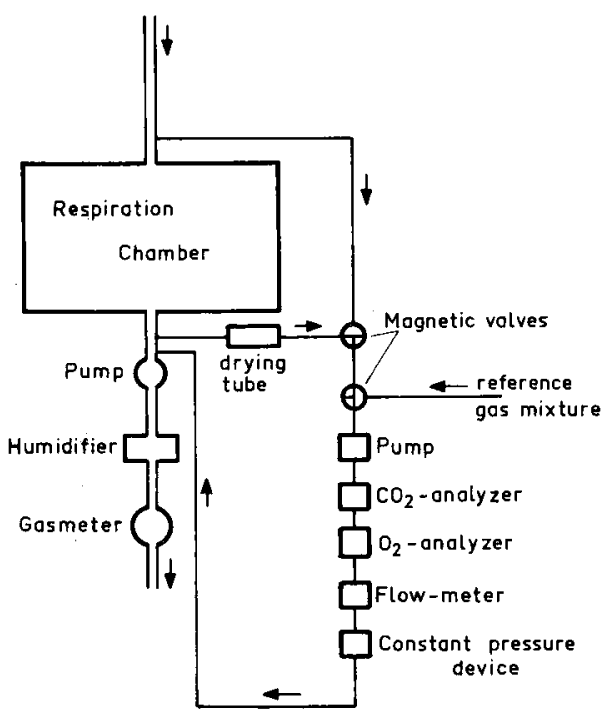

Fig. 1 Diagram of apparatus used for measuring gas exchange

means of the following formula:

$\frac{\text { M.E. }}{\mathrm{g} \text { diet }}=\frac{\text { gross energy }}{\mathrm{g} \text { diet }}-\frac{0 / 0 \mathrm{Cr}_{2} \mathrm{O}_{3} \text { in diet }}{0 / 0 \mathrm{Cr}_{2} \mathrm{O}_{3} \text { in excreta }} \times \frac{\text { gross energy }}{\mathrm{g} \text { excreta }}$

The reason for choosing the indicator method is that in our experience when layers are fed ad libitum, even over a 5-day experimental period, it is difficult to synchronize the diet intake and resultant excreta owing to the irregularity of intake and excretion. Moreover when a cage contains more than one bird it is difficult to collect the excreta quantitatively. Recovery of a carefully measured dose of $\mathrm{Cr}_{2} \mathrm{O}_{3}$ per gelatine capsule administered to four fowls was $100 \%$ and this was taken as an indication of the reliability of the method.

The excreta were collected every 24 hours and dried in a freeze-drier for 18 hours at $-15^{\circ} \mathrm{C}$ and $0.05 \mathrm{~mm} \mathrm{Hg}$. The heat of combustion of diet and dried excreta was determined in duplicate with an adiabatic calorimeter (the standard deviation of a single determination was $0.3 \%$ ).

$\mathrm{Cr}_{2} \mathrm{O}_{3}$ in the diet and excreta was determined by means of an extensively modified Czarnocki (1961) method in which $4 \mathrm{~g}$ of feed or $1.4 \mathrm{~g}$ of dried excreta were mixed with $10 \mathrm{ml}$ of $65 \%(\mathrm{w} / \mathrm{v}) \mathrm{HNO}_{3}$ and carefully heated to boiling temperature in a $100 \mathrm{ml}$ Kjeldahl flask. As much $\mathrm{HNO}_{3}$ as possible was evaporated. After cooling, $25 \mathrm{ml}$ of distilled water was added and the contents of the flask filtered over filter paper. Both the flask and the filter were atferwards rinsed with water. When a great deal of fat was present the filter was also washed with acetone and then dried. The filter was then reintroduced into the flask and $3 \mathrm{ml}$ of $96 \%(\mathrm{w} / \mathrm{v}) \mathrm{H}_{2} \mathrm{SO}_{4}$ and a few drops of $65 \%(\mathrm{w} / \mathrm{v})$ $\mathrm{HNO}_{3}$ were added. The contents were then very carefully heated over a micro-burner to boiling point; a few drops of nitric acid were continuously added until the liquid in the flask remained light brown; after cooling, $5 \mathrm{ml}$ of $70 \%$ (w/v) $\mathrm{HClO}_{4}$ were added and the contents again brought to the boil. After boiling for some time the liquid in the flask turned orange. Boiling was continued gently for a further 10 minutes until 
all the $\mathrm{Cr}_{2} \mathrm{O}_{3}$ was converted to dichromate. After the flask had cooled, $50 \mathrm{ml}$ of distilled water was added. The liquid was boiled in order to expel dissolved chlorine gas. The contents of the flask were then transferred to a 1-litre graduated flask; after addition of $100 \mathrm{ml}$ of $20 \%(\mathrm{w} / \mathrm{v}) \mathrm{NaOH}$ the flask was filled to the gradation mark with distilled water. A part of the chromate solution was centrifuged and the extinction of the solution measured with reference to water at $370 \mathrm{~nm}$ in a spectrophotometer. Since with the effective band width of $0.15 \mathrm{~nm}$ the relationship between extinction and $\mathrm{Cr}_{2} \mathrm{O}_{3}$ content proved to be fully linear, there is no need to use standard solutions for extinctions of $0-2.0$, and in the formula used for calculating the M.E. the percentage of $\mathrm{Cr}_{2} \mathrm{O}_{3}$ may be replaced by the extinctions measured per gram of feed and excreta (cf. Eq. 4). In this method of determining chromic oxide there is no need to introduce corrections for a blank as in the Czarnocki (1961) method. Excreta or feed without $\mathrm{Cr}_{2} \mathrm{O}_{3}$ have an extinction of 0.000 . In the Czarnocki method $\mathrm{Fe}^{3+}$ ions and calcium are particularly disturbing. The extinctions were determined in triplicate. The standard deviation of a single determination was found to be $\pm 1.1 \%$.

Experiment I. The heat production of fasting laying White Leghorn hens housed one bird to a cage

For this experiment use was made of very light White Leghorns in full production for about 3 months (production about $80 \%$ ). Their respiratory exchange was measured for 24 hours after a fasting period of 24 hours at $20^{\circ} \mathrm{C}$. Prior to the experiment the birds were given ration II or I (Table 1 ) and housed at a temperature of $19^{\circ}-21^{\circ} \mathrm{C}$, only one bird being housed to a cage (floor surface $16 \mathrm{dm}^{2}$ ). All birds received artificial lighting for 17 hours a day. In all, the heat production was measured of 12 birds. The only measurements used for the experiment were of birds which were in full production before and after the experiment and laid an egg during the measurement period. The results are shown in Table 2.

Experiment II. The heat production of fasting laying White Leghorn hens housed two birds to a cage

For this experiment use was made of White Leghorn laying hens which had been in

Table 1 Composition of diets (ingredients in \% of total)

\begin{tabular}{|c|c|c|c|}
\hline Ingredients 1 & Diet $I$ & Diet $I I$ & Diet $I I I$ \\
\hline Corn, ground yellow & 55 & 55 & 43 \\
\hline Milo & - & - & 20 \\
\hline Oats & 25 & 17.5 & 10 \\
\hline Soybean oil meal extracted & 9 & 15 & 10 \\
\hline Peru fish meal & 5 & 7 & 5 \\
\hline Mineral mixture & 2 & 2 & 2 \\
\hline Alfalfa meal & - & - & 2.5 \\
\hline $\mathrm{CaCO}_{3}$ & 2 & 2 & 4 \\
\hline Dicalcium phosphate & 0.5 & - & 0.75 \\
\hline Vitamin mixture & 1.5 & 1.5 & 1.25 \\
\hline Animal fat & - & 一 & 1.5 \\
\hline $\begin{array}{l}\text { Metabolizable energy (determined; } \\
\text { in kcal per g dry matter) }\end{array}$ & 3.140 & 3.192 & 3.251 \\
\hline
\end{tabular}

1 In diets I and II oyster shell was fed ad libitum 
Table 2 Mean heat production of fasting laying hens at $20^{\circ} \mathrm{C}$

\begin{tabular}{lccc}
\hline $\begin{array}{c}\text { Animals } \\
\text { animals } \\
\text { animer of }\end{array}$ & $\begin{array}{c}\text { Mean body weight } \\
\text { of animals }(\mathrm{kg})\end{array}$ & $\begin{array}{c}\text { Mean heat } \\
\text { production per kg0.75 } \\
\text { (in kcal) }\end{array}$ \\
$\begin{array}{l}\text { Experiment I } \\
\text { White Leghorn } \\
\text { (one bird per cage) }\end{array}$ & 12 & $1.68(1.42-1.96)$ & $97.0(90.1-108)$ \\
$\begin{array}{l}\text { Experiment II } \\
\text { White Leghorn } \\
\text { (two birds per cage) }\end{array}$ & $6 \times 2$ & $1.68(1.34-2.08)$ & $98.0(92.6-106)$ \\
$\begin{array}{l}\text { Experiment III } \\
\text { Australorps } \times \text { R.I.P. } \\
\text { (two birds per cage) }\end{array}$ & $5 \times 2$ & $2.43(2.08-2.69)$ & $90.6(85.0-101)$ \\
\hline
\end{tabular}

production for 2 to 3 months (production about $80 \%$ ). The heat production was measured after a fasting period of 24 hours, two birds being invariably placed in one cage in the respiration chamber. The cage had a floor surface of $16 \mathrm{dm}^{2}$. Otherwise the conditions were the same as in Experiment I. Before the experiment, however, the birds were given ration III (Table 1). The results are shown in Table 2.

Experiment III. The heat production of a medium-weight breed of fasting laying hens The heat production of 10 medium-weight laying hens (Australorps $\times$ R.I.R.) was meas-

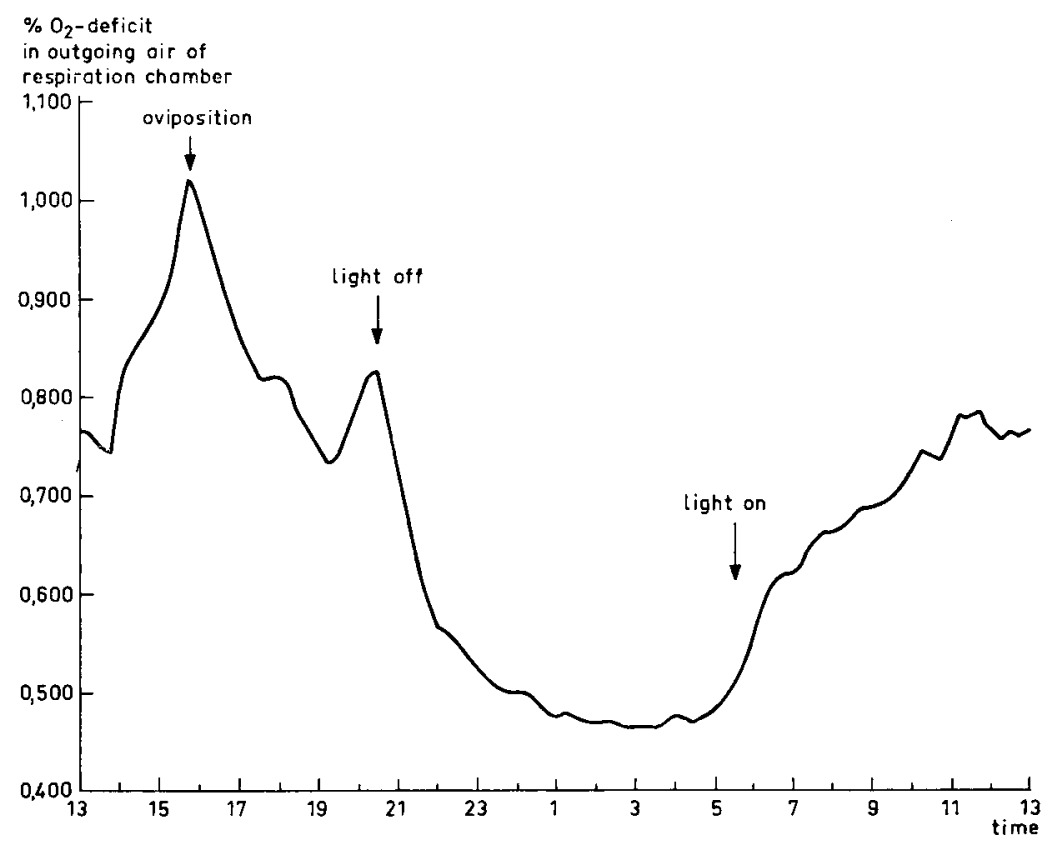

Fig. 2 24th recording of $\mathrm{O}_{2}$-deficit $(\%)$ in outgoing air of a respiration chamber with a laying hen fed ad libitum ( 9 h darkness - 15 h light $)$ 
ured in the same manner as in Experiment II after a fasting period of 24 hours. These birds were also in full production before, during and after measurement (about 80\%). The results are shown in Table 2.

Experiment IV. Determination of the energy balance of White Leghorn hens of different production levels and body weight, fed ad libitum

Only White Leghorn hens were used for this experiment. In all, 22 observations were made. The birds were housed in the same cages as in Experiments I, II and III. Three observations were made with one bird to a cage fed on ration II ; the average heat production of three 24-hour periods was considered to be a single observation. Also the heat produced by one bird every two hours was measured over a 24 -hour period (Fig. 2). The birds had been in production for about two months. Six observations were made with two birds to a cage, one cage being placed in the respiration chamber at the same time. Measurements were made for $2 \times 24$ hours. The average of $2 \times 24$ hours was considered to be a single observation. The birds were given ration III (Table 1) and laid for about one to two months, so that production was very high. 13 observations were made with two birds to a cage and two cages in the respiration chamber, viz four birds in all. Measurements were made $4 \times 24$ hours, the average of $4 \times 24$ hours being considered as a single observation. These birds were also given ration II and were from the same flock as those which had been laying for one to two months. But the measurements were made 10 to 12 months later, so that in general production was low and the

Table 3 Experiment IV. Energy balance of laying White Leghorn hens of different production levels and body weights, fed ad libitum. $M E, E E$ and $B$ in kcal per animal per 24 hours

\begin{tabular}{|c|c|c|c|c|c|c|c|}
\hline Animals & Diet & $\begin{array}{l}\text { Mean } \\
\text { body } \\
\text { weight }\end{array}$ & $\begin{array}{l}\text { Intake } \\
\text { of } M E\end{array}$ & $E E$ & $M E-H$ & $\boldsymbol{B}$ & $\begin{array}{c}\text { Mean heat } \\
\text { production } \\
\text { (hours) }\end{array}$ \\
\hline 1 & II & 2,00 & 289 & 71 & +75 & + & $3 \times 24$ \\
\hline 2 & II & 1,67 & 225 & 47 & +46 & -1 & $" \quad$, \\
\hline 3 & II & 1,92 & 302 & 80 & +106 & +26 & $"$, \\
\hline $4+5$ & III & 1,80 & 277 & 62 & +59 & -3 & $2 \times 24$ \\
\hline $6+7$ & III & 1,73 & 253 & 69 & +68 & -1 & , , , \\
\hline $8+9$ & III & 1,88 & 291 & 58 & +89 & +31 & , \\
\hline $10+11$ & III & 1,65 & 281 & 77 & +96 & +19 & , \\
\hline $12+13$ & III & 2,20 & 335 & 52 & +81 & +29 & $"$ \\
\hline $14+15$ & III & 1,46 & 244 & 68 & +63 & -4 & $"$, \\
\hline $16+17+18+19$ & III & 1,71 & 227 & 0 & +60.3 & +60.3 & $4 \times 24$ \\
\hline $16+17+18+19$ & III & 1,80 & 254 & 0 & +66.8 & +66.8 &,$\quad$, \\
\hline $20+21+22+23$ & III & 2,10 & 153 & 0 & $-54,0$ & -54.0 & $" *$ \\
\hline $24+25+26+27$ & III & 2,08 & 244 & 4,5 & +30.3 & +25.8 & $"$ \\
\hline $24+25+26+27$ & III & 2,09 & 232 & 4,3 & +26.9 & +22.6 & $"$ \\
\hline $28+29+30+31$ & III & 2,39 & 287 & 40,4 & +43.9 & $\begin{array}{r}+3.5 \\
+\quad 3\end{array}$ & , \\
\hline $16+17+32+33$ & III & 2,35 & 355 & 56,7 & +106.4 & +49.7 & $"$ \\
\hline $28+29+36+31$ & III & 2,40 & 321 & 58,6 & +76.7 & +18.1 & $"$ \\
\hline $30+31+32+33$ & III & 1,96 & 266 & 9,3 & +63.3 & +54.2 & $"$ \\
\hline $26+27+34+35$ & III & 2,13 & 289 & 62,7 & +50.7 & -11.8 & $"$ \\
\hline $32+33+36+37$ & III & 2,31 & 188 & 4,4 & $+5,0$ & $+\quad 0.6$ & , \\
\hline $38+39+30+31$ & III & 2,24 & 253 & 45 & +35.3 & -9.7 & , \\
\hline $16+17+36+37$ & III & 2,21 & 172 & 23,4 & 一 6.9 & -30.3 & ", \\
\hline
\end{tabular}

* Birds in full moult; observation not used for calculation of regression 


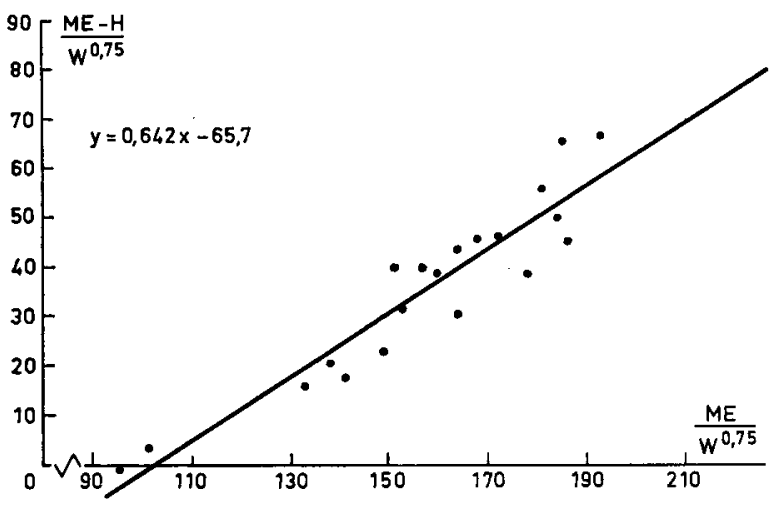

Fig. 3 Regression of energy gain on metabolizable energy of laying White Leghorn hens fed ad libitum

body weight higher. Before the measurements were taken the birds had been housed for some time at $19^{\circ}-21^{\circ} \mathrm{C}$. In all 22 birds were employed for the latter 13 observations, so that most birds had two sessions in the respiration chamber. The observations are summarised in Table 3. The last 19 observations consequently relate to birds taken from a large-scale comparative experiment with laying hens in batteries and on litter (Stappers, 1969). In one observation the birds concerned were in full moult; these exhibited a negative balance and a decline in body weight. With the exception of these moulting birds, all observations were used for calculation the regression from $\frac{\text { M.E. }-\mathrm{H}}{\mathrm{W}^{\mathbf{0 . 7 5}}}$ to $\frac{\text { M.E. }}{\mathrm{W}^{\mathbf{0 . 7 5}}}$

In the case of a negative, B was treated in the manner defined under the heading Calculations, definitions and nomenclature. The regression equation found was: $\mathrm{Y}=0.642 \mathrm{X}$ - 65.7 (Fig. 3).

\section{Discussion}

A comparison of the results of the three experiments with fasting laying hens shows that the individual variation in the results is high but that no difference is evident between Experiments I and II ; the animals' heat production was not influenced by the fact of their being housed alone or two to a cage. The heat production per $\mathrm{W}^{0.75}$ of the medium-weight layers was slightly lower than that of the White Leghorns. The difference is not significant. This observation was also made by Waring and Brown (1965, 1967). It is possible that genetic factors may be responsible for this difference, but we believe a more likely cause is the egg production, since we can assume that the heat production due to egg production is the same for light and heavy birds, i.e. independent of $W^{0.75}$. For all observations of fasting birds the measured heat production was plotted against $W^{0.75}$. From this data it is possible to calculate the regression from heat production to $W^{0.75}: H=85.2 \times W^{0.75}+16.6$. In view of this result there does seem to be a tendency, although not significant, for a constant heat production which is independent of $\mathrm{W}^{\mathbf{0 . 7 5}}$. The calorific value of an egg is about $90 \mathrm{kcal}$. If in view of the above regression equation we assume that about $17 \mathrm{kcal}$ of heat are produced from body reserves for each egg, this would imply an efficiency of $84 \%$. We believe, therefore, that it is reasonable to assume that about $20 \mathrm{kcal}$ of heat produced from the body 
reserve is evolved per 100 egg calories. Moreover in Experiment IV only a few observations were made in which there was a negative balance of any significance (Table 3), so that for this experiment the exact size of the correction for negative balance is of minor importance. If a large numer of observations are available, this correction could also be estimated from statistical calculations. In his experiments with milk cows van Es (1969) also assumed an about $80 \%$ efficiency of the milk energy produced from body reserves. It follows from the regression equation calculated from the data of $\mathrm{Ex}$ periment IV (Fig. 3) that the efficiency of utilization of the metabolizable energy for egg production and any growth was about $64.2 \%( \pm 5.5)$ in these experiments. The maintenance requirement may be estimate at $102 \pm 7.6 \mathrm{kcal}$ per unit of metabolic weight. Consequently the efficiency of utilization of M.E. for production in these experiments differs substantially from the value of about $85 \%$ reported by Waring and Brown (1965, 1967). It follows from Fig. 3 that in most cases the major part of the metabolizable energy was used for maintenance (60 to $70 \%$ ). This fact makes it difficult to determine accurately the efficiency of utilization of M.E. for egg production. The slight variation in body weight is a further obstacle in the calculations. Hence it is not surprising that the standard deviations are fairly considerable. The efficiency of utilization $(64.2 \%)$ is on the low side. This is caused mainly by two observations (Fig. 3) with low M.E. intake. Omitting these two observations would give an efficiency of $73.3 \%$ and a maintenance requirement of $111 \mathrm{kcal}$. However we have no reason for this; there were no signs of molt or illness. Another possibility could be that the regression line is not linear. However the number of observations near the point $\mathrm{Y}=0$ is too small to prove a curvilinear relationship.

Most birds in Experiment IV were selected from a group of some thousands of hens maintained under practical conditions for the purpose of comparing the effect of keeping layers on litter and in batteries. The diet and lighting period were also the same, thus permitting a comparison between the results of the laboratory and practical experiments (Stappers, 1969). The only data used for the comparison were those available from the age of 30-78 weeks, i.e. from fully grown adult birds. The following data were known of these birds per 12-week period: body weight and growth, percentage egg production and egg weight, food intake and M.E. content of the food.

It was assumed that the growth of these birds was solely in the form of fat retention. The latter is usually accompanied by some loss in tissue moisture. For fattening calves van Es (1969) found that $1 \mathrm{~g}$ of fat retention corresponded to $0.6 \mathrm{~g}$ of growth and we have also kept to this figure. This means that each gram of growth represents a retention of $15,8 \mathrm{kcal}$. The energy content of $1 \mathrm{~g}$ of whole egg (including the shell) was found to be $1,48 \mathrm{kcal}$. A total of 1,020 battery hens and 300 others kept on litter were included in the calculation. In this way it was possible to calculate the average daily production of calories per 12-week period. It was also assumed that the efficiency of utilization of metabolizable energy for production (eggs and growth) was equal to that of the laboratory birds $(64.2 \%)$. Hence it was possible to calculate the total amount of M.E. required for production. Deducting this from the total amount of M.E. absorbed we obtain the maintenance energy used (Table 4). It can be seen from this table that the maintenance energy calculated in this way is higher in the practical experiment than in the laboratory experiment, especially during the winter months. For the same productivity level, the food intake of the laboratory animals was invariably less than in the practical experiment which was conducted, in an unheated, well ventilated poultry house.

It is hardly likely that the efficiency of utilization of metabolizable energy for produc- 
Table 4 Calculated maintenance energy of W.L. hens in a practical feeding experiment, assuming the efficiency of utilization of ME for production (eggs and growth) was $64.2 \%$. All values per $\mathrm{kg} 0.75$

\begin{tabular}{|c|c|c|c|c|c|}
\hline $\begin{array}{l}\text { Age in } \\
\text { weeks }\end{array}$ & Period & $\begin{array}{c}\text { Intake } \\
\text { (kcal) } \\
M E \\
I\end{array}$ & $\begin{array}{c}\text { Energy } \\
\text { (kcal) } \\
\text { produced } \\
P\end{array}$ & $\begin{array}{l}\text { Total energy } \\
\text { (kcal) required } \\
\text { for production } \\
\frac{100}{64.2} \times P=P^{\prime}\end{array}$ & $\begin{array}{c}\text { Calculated for } \\
\text { maintenance } \\
I-P^{\prime}\end{array}$ \\
\hline
\end{tabular}

Hens on battery cages; 1012 animals

$\begin{array}{llllll}30-42 & \text { Aug.-Nov. } & 200 & 46 & 72 & 128 \\ 42-54 & \text { Nov.-Feb. } & 205 & 36 & 56 & 149 \\ 54-66 & \text { Feb.-May } & 186 & 39 & 61 & 125 \\ 66-78 & \text { May-Aug. } & 169 & 31 & 48 & 121\end{array}$

Hens on litter; 300 animals

$\begin{array}{llllll}30-42 & \text { Aug.-Nov. } & 210 & 46 & 72 & 138 \\ 42-54 & \text { Nov.-Feb. } & 210 & 38 & 59 & 151 \\ 54-66 & \text { Feb.-May } & 194 & 38 & 59 & 135 \\ 66-78 & \text { May-Aug. } & 182 & 33 & 52 & 130\end{array}$

tion was less in the practical experiment than in the laboratory one, this efficiency mainly depending on biochemical conversions in the animal organism. In the practical experiment, however, 5 birds were housed per cage measuring $53 \times 42 \mathrm{~cm}$, or $456 \mathrm{~cm}^{2}$ of space per bird, and in the laboratory experiment two birds were housed per cage measuring $40 \times 40$, or $800 \mathrm{~cm}^{2}$ of space per bird. Wood-Gush and Gilbert's (1969) experiments show that when housed in a battery some birds may grow very restless a few hours before oviposition; the writers observed 'attempts to escape' and 'nest building' activities. It is possible that these frustrations were greater in the more crowded practical battery than in the laboratory battery. At any rate these nest building activities result in a lower efficiency of energy utilisation for production. During our own experiments with one bird to a cage we did in fact note a marked peak in the oxygen consumption of some birds shortly before oviposition (Fig. 2).

It is clear, however, that in general the birds will grow more restless, i.e. require a higher level of maintenance, in a more crowded battery, despite the additional warmth the birds provide for each other.

It is also evident that the maintenance requirement was higher during the winter than in the summer months. In the laboratory experiments the temperature was constantly held at $20^{\circ} \mathrm{C}$ during the day and night. An average 24-hour temperature of $20^{\circ} \mathrm{C}$ may be considered high under the practical conditions obtaining in Holland. Various studies, e.g. Shannon and Brown (1969) and Romijn (1969), might be taken as evidence that the maintenance requirement continues to fall even at temperatures of over $5^{\circ} \mathrm{C}$ when the ambient temperature rises to above $30^{\circ} \mathrm{C}$. In practice, moreover, the night temperature will usually be lower than the day one, whereas the animals' heat production is highest in the daytime, and this may militate against an economic utilization of the energy. We believe therefore that the animals' higher maintenance requirement under practical conditions is chiefly due to the lower average ambient temperature.

Table 4 also shows that the calculated maintenance requirement for birds kept on litter is slightly higher than for the battery birds, except in the winter months. This greater maintenance requirement may be explained by assuming that the animals kept on litter moved about more frequently. 
To sum up, we can conclude from these experiments that respiration tests enable the metabolizable energy of laying hens to be divided into a maintenance part and a part required for production, provided a fairly large number of experimental animals are available. It is still not entirely clear which environmental factors should be taken into consideration. It is very important to study these factors with a view to obtaining a better understanding of the energy metabolism of laying hens.

\section{Acknowledgment}

The author wishes to thank Mr J. Dieker and Mr G. Wernsen for technical assistance and Ir G. J. M. van Kempen for advice on statistical problems.

\section{References}

Blaxter, K. L., 1962. The energy metabolism of ruminants. Hutchinson, London, p. 262.

Brouwer, E., 1964. Report of sub-committee on constants and factors. Proc. 3rd Symp. Energy Metabolism (Troon, 1964), p. 441.

Combs, G. F., 1960. A method for calculating the methionine requirements of the laying hen. Feedstuffs 32 (19) 18

Czarnocki, J., J. R. Sibbald \& E. Evans, 1961. The determination of chromic oxide in samples of feed and excreta by acid digestion and spectrophotometry. Canad. J. Anim. Sci. 41: 167-179.

Es, A. J. H. van, E. J. van Weerden \& A. M. Frens, 1966. Wärmeproduktion, Wasserverdünstung und Energiestoffwechsel bei Mastkälbern, gefüttert mit einem flüssigen Milchersatzfutter. Z. Tierphysiol., Tierernähr. Futtermittelk. 21: 25-34.

Jenkinson, G. M., L. G. Young \& G. C. Ashton, 1967. Energy metabolism and body composition of weanling pigs. Canad. J. Anim. Sci. 47: 217-225.

Nehring, K., R. Schiemann, L. Hoffmann \& W. Jentsch, 1961. Die Verwertung reiner Nährstoffe. Arch. Tierernähr. 11: 359-369.

Romijn, C. \& E. L. Vreugdenhil, 1969. Energiebalans en warmteregulatie bij de witte leghorn. Tijdschr. Diergeneesk. 94: 427-453.

Shannon, D. W. F. \& W. O. Brown, 1969. The period of adaptation of the fasting metabolic rate of the common fowl to an increase in environmental temperature from $22-28^{\circ} \mathrm{C}$. Br. Poult. Sci. 10 : 13-18.

Stappers, H. P., 1969. De huisvesting van leghennen op de batterij en op strooisel tijdens de opfok en de legperiode. Veet. Zuivelber. 12: 31-36.

Struss, F., 1958. Automatische Messung des Gaswechsels bei langfristigen Respirationsversuchen. Proc. 1st Symp. Energy Metabolism (Copenhagen, 1958), p. 112.

Vermorel, M. \& J. Keller, 1967. Utilisation énergétique, par le rat en croissance, des principales céréales en acides aminés. Annls Zootech. 16: 223-234.

Waring, J. J. \& W. O. Brown, 1965. A respiration chamber for the study of energy utilization for maintenance and production in the laying hen. J. agric. Sci. 65:139-146.

Waring, J. J. \& W. O. Brown, 1967. Calorimetric studies on the utilization of dietary energy by the laying White Leghorn hen in relation to plane of nutrition and environmental temperature. J. agric. Sci. 68 : 149-155.

Wood-Gush, D. G. M. \& A. B. Gilbert, 1969. Observations on the laying behaviour of hens in battery cages. Br. Poult. Sci. $10: 29-36$. 